[Formation of the spiritual potential of student youth]. Kyiv.

7. Otych, O. M. (2009). Mystetstvo u systemi rozvytku tvorchoyi indyvidual'nosti maybutn'oho pedahoha profesiynoho navchannya: teoretychnyy ta metodychnyy aspekty. [Art in the system of development of creative individuality of the future teacher of professional training: theoretical and methodical aspects]. Chernivtzhi.

8. Padalka, H. M. (1999). Profesiyno-tsilisnyy pidkhid $i$ yoho realizatsiya $v$ umovakh khudozhn'oyi osvity maybutn'oho vchytelya (na materiali muzychnykh dystsyplin). [Professional-holistic approach and its implementation in the conditions of art education of the future teacher (on the material of musical disciplines)]. Kyiv.

9. Reyzenkind, T. I. (1995). Teoriya i praktika kompleksnogo podkhoda $k$ probleme vzaimodeystviya iskusstv $v$ professional'noy podgotovke uchitelya muziki. [Theory and practice of an integrated approach to the problem of interaction of arts in the professional training of a music teacher]. Kyiv.

10. Rudnyts'ka, O. P. (2001). Svitohlyadna funktsiya mystetstva. [Worldview function of art]. Kyiv.

11. Shevnyuk, O. L. (2003). Kul'turolohichna osvita maybutn'oho vchytelya: teoriya $i$ praktyka. [Cultural education of the future teacher: theory and practice]. Kyiv.

\section{ВІДОМОСТІ ПРО АВТОРІВ}

ЯкИМЧУК Олена Миколаївна кандидат мистецтвознавства, старший викладач кафедри музикознавства, інструментальної підготовки та хореографії Вінницького державного педагогічного університету імені Михайла Коцюбинського.

Наукові інтереси: професійна підготовка майбутніх учителів музичного мистецтва.

UDK 317. 11.78

DOI: 10.36550/2415-7988-2021-1-195-154-159
УТЕШЕВА Наталія Михайлівна викладач Літинської музичної школи.

Наукові інтереси: професійна підготовка майбутніх учителів музичного мистецтва.

СОМИК Олександр Миколайович доктор філософії, викладач кафедри музикознавства, інструментальної підготовки та хореографії Вінницького державного педагогічного університету імені Михайла Коцюбинського.

Наукові інтереси: професійна підготовка майбутніх учителів музичного мистецтва.

\section{INFORMATION ABOUT THE AUTHORS}

YAKYMCHUK Olena Mykolayivna -

Candidate of Art History, Senior Lecturer of the Department of Musicology, Instrumental Training and Choreography of Vinnytsia State Pedagogical University named after Mykhailo Kotsyubynsky.

Circle of scientific interests: professional training of future music teachers.

UTESHEVA Natalia Mykhailivna - a Teacher at the Lityn Music School.

Circle of scientific interests: professional training of future music teachers.

SOMYK Oleksandr Mykolayovych Doctor of Philosophy, Lecturer of the Department of Musicology, Instrumental Training and Choreography of Vinnytsia State Pedagogical University named after Mykhailo Kotsyubynsky.

Circle of scientific interests: professional training of future music teachers.

Стаття надійшла до редакиї 17.04.21 p.

lecturer at the Dertment of Music Theor Natalia Georgievna Southukrainian national K. D. Ushinsky Pedagogical University ORCID:https://orcid.org/0000-0002-2326-1743 e-mail: nroitenko@gmail.com

\title{
FORMATION OF VALUE ORIENTATIONS OF STUDENTS-VOCALISTS
}

\begin{abstract}
Statement and grounding of the urgency of the problem. At the present stage of development of Ukrainian society, the requirements for the personality of the teacher are significantly increasing, which is associated with global social, economic, socio-cultural changes taking place in our country and the world, as well as Ukraine's integration into the European sociocultural space.

The main requirements for the level of teacher training are contained in such state
\end{abstract}

documents as the Law of Ukraine «On Education», the State National Program «Education» («Ukraine of the XXI Century»), the State Standard of Higher Education, Conceptual Principles of Teacher Education Development and its Integration European educational space. These documents guide teachers and scientists on the comprehensive development of the specialist's personality, the acquisition of personal professionally significant qualities, the development of his creative potential, 
opportunities for self-realization.

In the modern pedagogical system, the functions of the teacher have significantly expanded, which requires from the teacher high mobility, ability to adapt to new conditions and demands of society, creative approach to their professional duties, high level of knowledge, skills and integrative thinking.In modern conditions of socio-cultural development, the problem of formation of value orientations of students-musicians becomes especially actual. It is generally accepted that music plays a special role in the life of the individual, due to its ability to have a profound impact on the spiritual world of a man. This action becomes much greater if the music affects not only externally (passive or active perception), but is also directly reproduced by the performer. In the process of performing, a deeper comprehension of a musical work continues, depending on its cognitive complexity, there is a positive or negative impact on the currently formed hierarchy of personal values. The value orientations of students in the process of musical performance are a prerequisite for the disclosure of aesthetic potentials, adjust not only the musical and aesthetic interests, but also in general the needs, tastes, ideals, views of young people and more. Acquiring these qualities, the individual joins the accumulated by mankind true values of life, culture and professional activity.

The modern stage of music education is the foundation in the spiritual and moral development of the student, when the problem of value orientations of the student is considered as the most important element of the internal structure of personality, which allows to orient in the material and spiritual culture of society.

Analysis of recent research and publications. Nowadays, the quality of professional training of future music teachers has led to a significant change in the system of professional and value orientations of students. Many researchers point out that the professional and value orientations of students are often dominated by a pragmatic rather than a spiritual aspect. The value content of the profession, its spiritual and moral potential remain beyond the attention of the future teacher. According to scientists (E. B. Abdulin, G. M. Tsypin, E. V. Nikolaeva, A. V. Toropova, etc.) the main feature of reflexive manifestations is associated with deep and at the same time «intimate» aspects of the personality of a teacher-musician, with one's individual temperament and special personal understanding of «freedom» and «creativity» and is characterized by the relationship of logicalconstructive and artistic-aesthetic beginning. As a result, the teacher-musician becomes aware of the nature and content of the attitudes of the music teacher to various cultural and professional values that determine the value content of professional orientations.

In scientific works of the last decades there are the questions connected with improvement of axiological and professionally-pedagogical preparation of the teacher of musical art and professionally-personal formation of the teachermusician (T. Mariupolskaya, I. Medvedeva, I. Nemykina, A. Nikolaeva, L. Rapatskaya, E. Sizova, B. Tselkovnikov, A. Shcherbakova and others).

The scientific literature emphasizes the importance of values as the basis for the development of society (O. Drobnytsky, A. Zdravomyslov, V. Tugarinov, etc.). Various aspects of the formation of professional value orientations of students of art and pedagogical specialties are studied in the works of Ukrainian and Russian scientists, in particular: professional and pedagogical values of teachers (S. Badyul, S. Yermakova, R. Mironova, V. Ossovsky, S. Khmara, E. Shiyanov, etc.), value orientations of youth in the field of culture (N. Baklanov, O. Demyanchuk, V. Dryapika, Y. Malyshev, G. Padalka, O. Semashko, N. Yarantseva, etc.).

The authors of dissertation research in recent years emphasize the important role of the axiological component in the process of professional training of future teachers (V. Volkova, V. Denisenko, D. Matsko, N. Savchenko, Y. Solovyova, O. Sofishchenko, N. Tkachova, etc.). Scientists are actively searching for ways to effectively form professional and pedagogical value orientations of future teachers of various specialties.

Different aspects of professional orientations of the future music teacher are reflected in the dissertations of I. Adoevtseva, O. Asatryan, O. Germanova, I. Kolomiets, A. Lysenko, E. Pavlova, O. Shchelkanova, T. Fursenko and others.

The purpose of the article is to investigate the problem of formation of value orientations of future students-vocalists during their studies at universities, taking into account the peculiarities of the students'contingent and the specifics of education.

The main material of the study. Historical and genetic analysis of the problem of formation of value orientations of the individual allows us to conclude that values and value orientations belong to the cross-cutting issues of spiritual and socio-cultural development of society. It is noted that in the Renaissance there was a shift of value dominance in the hierarchy of personal value orientations of the individual from God to man, and then - from the values of reality to the value as the significance of reality.

Modern research (O. Drobnytsky, A. Zdravomyslov, V. Tugarinov, etc.) gives 
grounds to determine that values are the significance of the objects of the surrounding reality for man and society. They have a complex mental representation, are both motivational and cognitive formations of the worldview, which are integrated into a single semantic sphere, giving the individual a certain integrity. Values are conditional hierarchy in the structure of personality and include universal, national, professional, personal values, etc.

In the scientific literature there are different approaches to the definition «Value orientations of personality», which are considered as: an element of the system of dispositions of personality, which are at the highest hierarchical level (V. Yadov); needs, motives of personality (A. Maslow); personal meanings (W. Frankl); orientation of personality, attitudes, beliefs, beliefs (G. Zaleski, A. Zdravomyslov, F. Znanetsky, U. Thomas, V. Tugarinov); factor motivating human behavior, character and inclinations (B. Ananiev); mechanism of regulation of activity (V. Serzhantov, V. Shadrykov, etc.), socially determined and fixed in the psyche of the individual focus on the goals and means of activity (E. Dneprov); value attitude to the world, professional activity, to oneself as a subject of life creation (M. Kagan, M. Kazakina, A. Kiryakova).

Value orientations are considered as socially fixed guidelines for certain material or spiritual values that are formed in the process of human mastery of the natural and social world and determine its behavior in specific life situations, life strategy. Value orientations are subjective, characterize the spiritual world of a particular person as a being who thinks, seeks, suffers, acts, contains the life experience of a particular individual, are the result of individual practice of mastering the social and natural world, which is unique and inimitable. Value orientations determine the general orientation of interests and aspirations of the individual, the hierarchy of individual preferences and patterns, the target and motivational program, the level of aspirations and prestigious preferences. The leading functions of value orientations should be recognized as follows: cognitive, developmental, motivational, evaluative, regulatory, socializing, prognostic.

In pedagogy, the value orientations of the teacher are seen as a central link in the structure of his personality, which determines the humanistic orientation of the teacher and his interaction with the world and with people, which expresses a specific understanding of the goals of human existence.

Scientists believe that the need to study the value orientations of future teachers is dictated primarily by the need to improve the system of general and professional education.
Value orientations have a decisive influence on both professional and personal selfdetermination of the teacher, they mediate all pedagogical activities. The leading conditions for the formation of professional and pedagogical orientation of the individual are the discovery of his pedagogical vocation and the formation of value orientations [1].

The analysis of scientific and theoretical works proves that the study of value orientations reveals various aspects of the interpretation of the concept. Scientists point out that value orientations are a personal formation and reflect a system of attitudes that characterize the attitude of the individual to professional activity (L. M. Khabayeva, E. B. Khramova, O. M. Shtab); value orientations are reflected in the professional consciousness of the specialist, his attitude to professional activity and determine the direction of his behavior as a subject of professional activity (T. P. Bobro, S. A. Koval, E. L. Rudneva, A. P. Spirin); value orientations are the core of the integrity of the individual and express the qualitative characteristics of the semantic structure of the consciousness of the specialist, serve as a criterion for the implementation of social and professional activity (V. Lastivka, O. Sidorenko, V. Slastyonin, G. Chizhakova, S. Khmara); they constitute the basic characteristics of the professional's personality, the main content of which is the system of relations to the integrative profession and readiness to be realized in professional activity (E. Velychko, N. Zykova, I. Kamalova); they are associated with a high level of awareness of the values of the profession, with the construction of subjective preferences, with the acceptance of certain values (N. Laphanova, L. Magamadova, G. Mikheeva, N. Pryanikova, E. Shiyanov).

Professional values reflect the content of any profession and are therefore important for studying the professional activities of a teachermusician.

In recent years, we can see the growing interest of teachers-musicians to value orientations in music education of the younger generation, which is stimulated by the development of an axiological approach to pedagogical phenomena, as well as attention to the formation of value orientations of music teachers.

«For all types of professional musical activity», - points out O. Sizova, -«the most important factor is the motivation and value attitude to the profession, which is expressed in the desire to work and awareness of the importance of the work performed. This acts as the main and main condition for the functioning of a specialist in a professional music environment» [4, p. 50]. 
We are close to the position of A. Lysenko, who believes that the value orientations of the future music teacher are a generalized, specific form of professionally oriented value choice, which expresses the attitude of the future music teacher to various professional values and, above all - to the child as a subject of musical development and education, to music as a means of personal development and to their interaction in the creative musical and pedagogical process [2].

Music educators emphasize that the value orientations of music teachers should act as regulators of needs, interests, tastes, ideals of his students and further target them to the development and realization of values in all spheres of life, to awaken activity in independent choice of spiritual universalvalues [6].

It should be noted that the training of the future student-vocalist in the university initially has specific features that are due to a number of objective and subjective factors and significantly affect the formation of value orientations of students. Consider them in more detail.

First, future music teachers experience quite serious difficulties in learning, starting with the first year. They are associated with the psychological characteristics of age and the difficulties of socio-psychological adaptation to the conditions of the educational process in the pedagogical university, which differs significantly from the school and secondary special educational institutions (schools, colleges, etc.). Quite important problems are the increased physical and psychological load, great emotional stress in the performance process, a variety of musical activities that students must master (instrumental, musical-theoretical, vocal, ensemble, choral, educational, lecture activities, etc.).

Secondly, the difficulties in teaching future musicians in universities depends on very different levels of prior musical training of students. About $60 \%$ of students do not have a primary music education, do not have the basics of musical literacy, performance skills, music theory. Some students, on the contrary, have significant experience in music in children's art clubs and studios, folk ensembles, amateur groups, and so on.

O. Piskunova considers students as a socioage category, which, according to the periodization of $\mathrm{B}$. Ananiev, belongs to the second stage of youth, and according to D. Feldstein - to the late period of youth [5]. According to the concept of D. Feldstein, the processes of socialization and individualization are interconnected, interdependent and originate within each other [5]. Students' age opens a new stage in individualization, associated with determining their place in the world, awareness of their own identity and uniqueness. During the period of study at the Pedagogical University, the student's personality undergoes quantitative and qualitative changes, as it is time to form a person's social maturity, the formation of one's worldview, beliefs, ideals, tastes, needs and more [5].

Already in the very nature of learning (group and individual), a special style of interpersonal relationships is formed, which are built primarily on the emotional and personal level and are the result of a specially organized educational process in the system «student-teacher-student». The predominance of joint activities of teachers and students, which is manifested in playing a musical instrument, ensemble (instrumental, vocal), choir leadership, in the process of pedagogical practice is an important feature of teaching future music teachers. The student together with the teacher must be able to adjust their professional music and teaching activities; take personal responsibility for its results; be aware of the importance of professional music and pedagogical activities for others; strive for self-realization in the profession.

A music teacher is a specific profession that is associated with the art of music as a form of artistic creativity, where music and pedagogy are inextricably linked. Therefore, the development of two areas of special abilities - musical and pedagogical - is of special importance for the future music teacher. Hence there is another feature of learning - multifunctionality, as in a music lesson the teacher must act as a teacher and as a conductor, to prove himself as a vocalist, psychologist, educator, artist, screenwriter, director [1].

The values of professional activity of future specialists of art and pedagogical specialties (teachers of music disciplines, concert performers, artists of musical groups, conductors, choirmasters, etc.) include professional and pedagogical values and values of musical performance. Of particular importance in the process of their formation are acquired sociocultural situation in society, modern mass media, subcultural preferences of student youth, taking into account the specifics of student age as a period of intense self-awareness, professional and moral development, the establishment of life goals and positions.

Professional value orientations of students of art and pedagogical specialties include attitude to: universal and national values of culture; values that characterize the professional activity of a music teacher (values-knowledge, values-skills and values-quality); values that characterize the personal qualities of the teacher.

An essential component of the professional 
development of the future teacher of music is vocal training, because singing is one of the main activities of students in music lessons. Thanks to singing, students enrich the emotional sphere, knowledge about the culture of their country and other countries, develop vocal skills, and in a broad sense, the spiritual component of personality is formed, which is the main task of pedagogical activity in general.

L. Vasylenko believes that vocal training of students of music and pedagogical faculties is a process aimed at maximum development of their ability to deeply understand musical images and embody them in a perfect singing and performing form, students' awareness of the role of singing in life, cultural and musical development of personality, as well as the development of future teachers' skills to apply methods and organizational forms adequate to the tasks of vocal education of students. The content of vocal training is determined by the tasks that the future teacher will meet in the process of forming vocal culture of students. practical and psychophysiological components, aimed at forming the professional qualities of the singerperformer, teacher-musician, his artistic and aesthetic tastes, ability to creative activity in pedagogy and art.

L. Vasylenko believes that vocal training of students of music and pedagogical faculties is a process aimed at maximum development of their ability to deeply understand musical images and embody them in a perfect singing and performing form, students' awareness of the role of singing in life, culture and music. personality development, as well as the development of future teachers' skills to apply methods and organizational forms adequate to the tasks of vocal training of students [1, p. 9].

N. Roitenko rightly considers vocal training as a holistic complex system, which is a set of different components: subjects, objects, structure, methods, stages of development, as well as the diversity of existing connections between them [4].

Music performance as a factor in the formation of professional values of students of art and pedagogical specialties involves the use of the best samples of different types and genres of world and national music; constant improvement of musical and performing skills and interpretation of works; inclusion of future specialists in concert practice. The use of the best samples of different types and genres of world and national musical art in the process of music performance directly contributes to the student's acquisition of knowledge in the field of musical art and, in particular, understanding of its types, styles and genres. In addition, the performing repertoire of professional disciplines is being mastered. Systematic improvement of performing skills and interpretation of works contributes not only to mastering at a high level the technological aspects of performing training, but also a deep understanding of the concept of musical works; improving the organization of concert practice the creative development of the future teachermusician: professional knowledge and skills of the student, acquired during rehearsal activities, at the concert performance are mobilized and manifested in the technology of performance and interpretation of the musical work.

Based on the multifunctional nature of the activity, a modern music teacher must have an interconnected set of knowledge, skills and abilities in several areas: in music theory (harmony, analysis of musical works, musical literature, etc.); music pedagogy and psychology (psychology and pedagogy of music education, methods of music education, etc.); musical performance (instrumental music making, choral conducting, voice staging, etc.).

However, the main task of educating a future music teacher in a university is, in our opinion, to focus not on mastering individual subject knowledge, skills and abilities, but on the formation of a holistic system of professional competencies focused on the needs of secondary school.

Conclusions and prospects for further researches of directions. Summarizing the above mentioned, we can conclude that the features of the training of future studentsvocalists in the university are the specifics of the age of students associated with early career guidance and self-determination in the profession; in the organization of the educational process itself, due to the fact that individual classes are held on the main and additional musical instruments, solo singing, choral conducting; in the priority studying by future music teachers not only fundamental scientific knowledge, but practically necessary professional skills and abilities.

\section{СПИСОК ДЖЕРЕЛ}

1. Василенко Л.М.Взаємодія вокального і методичного компонентів у процесі професійної підготовки майбутнього вчителя музики: автореф. дис. ... кандидата пед. наук: спец. 13.00.02 «Теорія та методика навчання музики і музичного виховання» / Л. М. Василенко. К., 2003. 20 с.

2. Лапханова Н. С. Формирование профессионально-ценностных ориентаций у студентов университета: на примере естественногеографического факультета: автореф. дис. канд. пед. наук / Н. С. Лапханова. Курган, 2000. 194 с.

3. Лысенко А. В. Психолого-педагогические условия формирования профессионально-ценностных ориентаций будущего учителя музыки: дис. ... канд. пед. наук / А. В. Лысенко. Майкоп, 2005. 185 с.

4. Мозгальова Н. Г. До питання про мотивацію 
музичного мислення майбутніх учителів музики / Н. Г. Мозгальова // Творча особистість учителя: проблеми теорії i практики. 2003. Вип. 10. C. 196-201.

5. Ройтенко Н. О. Концептуальні засади педагогічного супроводу вокального розвитку майбутніх учителів музичного мистецтва / Н. О. Ройтенко // Наукові записки / Ред. кол.: В. Ф. Черкасов, В. В. Радул, Н. С. Савченко та ін. Випуск 155. Серія: Педагогічні науки. Кропивницький: РВВ КДПУ ім. В. Винниченка, 2017. 306 c. С. 101-104.

6. Сизова Е. Р. Организация и содержание профессиональной подготовки музыканта-педагога в условиях современного социума / Е. Р. Сизова М.: АПК и ППРО; Челябинск: ЧГИМ, 2007. 170 с.

7. Фельдштейн Д. И. Психология взросления: структурно-содержательные характеристики процесса развития личности / Д. И. Фильштейн. М. : Флинта, 1999. 672 с.

8. Фурсенко Т. Ф. Педагогические условия подготовки будущего учителя музыки и художественной культуры / Т. Ф. Фурсенко // Проблемы современного педагогического образования. Ялта: РВВ КГУ, 2011. Вып. 32. Ч. 1. C. $110-118$.

\section{REFERENCES}

1. Vasylenko, L. M. (2003). Vzayemodiya vokal'noho $i$ metodychnoho komponentiv u protsesi profesiynoyi pidhotovky maybutn'oho vchytelya muzyky. [Interaction of vocal and methodical components in the process of professional training of future music teachers]. Kyiv.

2. Lapkhanova, N. S. (2000). Formirovaniye professional'no-tsennostnykh oriyentatsiy u studentov universiteta: na primere yestestvennogeograficheskogo fakul'teta. [Formation of professional-value orientations among university students: on the example of the natural-geographical faculty]. Kurgan.

3. Lysenko, A. V. (2005). Psikhologopedagogicheskiye usloviya formirovaniya professional'no-tsennostnykh oriyentatsiy budushchego uchitelya muzyki. [Psychological and pedagogical conditions for the formation of professional and value orientations of the future music teacher]. Maikop.

4. Mozhalova, N. H. (2003). Do pytannya pro motyvatsiyu muzychnoho myslennya maybutnikh uchyteliv muzyky. [On the question of motivation of musical thinking of future music teachers]. Kuiv.

5. Roytenko, N. O. (2015). Kontseptual'ni zasady pedahohichnoho suprovodu vokal'noho rozvytku maybutnikh uchyteliv muzychnoho mystetstva. [Conceptual principles of pedagogical support of vocal development of future teachers of music]. Kropivnutskyi.

6. Sizova, Ye. R. (2007). Organizatsiya $i$ soderzhaniye professional'noy podgotovki muzykantapedagoga $v$ usloviyakh sovremennogo sotsiuma. [Organization and content of professional training of a musician-teacher in the conditions of modern society]. Chelyabinsk

7. Feldshteyn, D. I. (1999). Psikhologiya vzrosleniya: strukturno-soderzhatel'nyye kharakteristiki protsessa razvitiya lichnosti. [Psychology of growing up: structural and content characteristics of the process of personality development]. Moscow.

8. Fursenko, T. F. (2011). Pedagogicheskiye usloviya podgotovki budushchego uchitelya muzyki $i$ khudozhestvennoy kul'tury [Pedagogical conditions for the preparation of a future teacher of music and art culture]. Yaita.

\section{ВІДОМОСТІ ПРО АВТОРА}

БІтькО Наталія Георгї̈вна - викладач кафедри теорії музики та вокалу Південноукраїнського національного педагогічного університету імені К. Д. Ушинського.

Наукові інтереси: професійна підготовка майбутніх учителів музичного мистецтва.

INFORMATION ABOUT THE AUTHOR

BITKO Natalia Georgiivna - Lecturer at the Department of Music Theory and Vocal Theory of the K. D. Ushinsky South Ukrainian National Pedagogical University.

Circle of scientific interests: professional training of future music teachers.

Стаття надійшла до редакції 07.04.21 p.

БОРЩЕНКО Наталія Олександрівна аспірантка факультету мистецтв імені Анатолія Авдієвського Національного педагогічного університету імені М. П. Драгоманова ORCID:https://orcid.org/0000-0002-6063-5695 e-mail: natasju@yahoo.com

\section{ВИКОРИСТАННЯ ЗАСОБІВ АРТ-ТЕРАПІЇ У ФОРМУВАННІ ЕМОЦІЙНОЇ СТІЙКОСТІ ДІТЕЙ ДОШКІЛЬНОГО ВІКУ}

\author{
Постановка та обгрунтування \\ актуальності проблеми. Початок XXI \\ століття характеризується небувалим \\ прогресом науки і техніки, розвитком новітніх \\ інформаційних технологій, а разом 3 тим i
}

суспільними труднощами в адаптації до них, збільшенням тривоги через світову пандемію коронавірусу. Внаслідок глобальних та незворотних змін в житті людей з'являються стреси, дискомфорт, емоційні переживання, 